\title{
Die verband tussen opsig/tug en die leer en lewe van die gemeente*
}

\author{
JA Beukes
}

\section{INLEIDING}

Die veld wat deur ' $n$ onderwerp soos hierdie gedek moet word, is so wyd dat ' $n$ mens met die spreekwoordelike ossewa daarin kan draai. Om dié rede hoop ek gaan die opdraggewers my verskoon as ek dit ietwat anders stel. In die eerste plek gaan daar nie gehandel word oor presies wat met die opsig en tug bedoel word nie en tweedens gaan die "leer" effens links gelaat word. In breë trekke gaan ek die tema soos volg omskryf:

Slaag die kerklike opsig en tug daarin om as deel van al die verkondigingsgestaltes van die Kerk die evangelie te laat deurdring tot in die konkrete lewe van die gemeente.

In die lig van bogenoemde sal daar eerstens gekyk moet word na die oorsprong en doel van die opsig en tug en in watter mate dit in verband staan met die leer en lewe van die gemeente. Tweedens sal daar 'n paar opmerkings gemaak moet word oor die lewe van die gelowige. Laasgenoemde bring ons in die gesigsveld van die Christelike etiek. Derdens sal ons moet kyk na die vrae oor wie die opsighouers is en hoe hulle in bogenoemde doel slaag. Laastens sal daar gepoog word om 'n paar riglyne neer te lê oor hoe beter opsig en tug die "kwaliteit" van die gelowige se lewe kan verbeter.

Hierdie referaat gaan nie 'n diepsinnige teologiese argumentasie wees nie, maar 'n paar praktiese opmerkings in gewone Afrikaans.

\section{OORSPRONG EN DOEL VAN DIE OPSIG EN TUG}

Die oorsprong van die opsig en tug kan nêrens anders gevind word as in die barmhartigheid van God self nie. Calvyn (iv/xii) hou ook God se barmhartigheid in die oog as hy sê dat die tug bedoel is om

\footnotetext{
- Referaat gelewer voor die Predikantevergadering van die Nederduitsch Hervormde Kerk van Afrika op 18 September 1984.
} 
terug te roep na die saligheid. Dié wat getug word, mag nie as vyande gereken word nie, maar hulle moet vermaan word soos broers. As die goeie gesindheid uit die tug weggeneem word, verval dit tot niks anders as foltering nie (iv/xii/10). Die tug is medisyne wat nie doodmaak nie, maar gesond maak. Barmhartigheid is vir hom die sleutelwoord, want met die tug moet daar uit barmhartigheid verbeter word wat kan, en wat nie verbeter kan word nie, moet geduldig verdra en met liefde betreur en beween word (iv/xii/ii). Dit beteken egter nie dat die tug oorbodig is nie, want as die Kerk nalatig is om te vermaan, is dit skuldig voor God.

By die opsig en tug gaan dit nooit om die afdwing van reëls en regulasies nie, want Bybelse voorskrifte is altyd liefdesvoorskrifte van 'n genadige Vader wat wil sien dat sy kinders gelukkig en in vrede en harmonie lewe. Laasgenoemde feit lê al klaar 'n duidelike verband tussen opsig/tug en die lewe van die gelowige: Opsig en tug het 'n harmonieuse en gelukkige lewe in die oog wat alleen moontlik is deur die versoening wat God in Christus bewerkstellig het. Dit wil toesien dat die gelowige sal insien dat God die God van liefde is, op grond waarvan Hy geëer moet word. Hierdie "geëer word" kry gestalte in die lewe van die gelowige en omdat dit uit dankbaarheid geskied, maak dit die lewe van die gelowige 'n gelukkige lewe. 'n Dankbare mens is altyd 'n gelukkige mens.

Die opsig en tug het ten doel die daarstel van 'n ruimte en die skep van die moontlikheid waarbinne bogenoemde gestalte kan kry. Daarom dat die Nederduitsch Hervormde Kerk van Afrika die doel van die opsig en tug in sy Kerkwet en Bepalings soos volg omskryf:

"Om die eensgesindheid en eenheid van die geloof in die Kerk te bevorder en te bewaar, en om almal in gehoorsaamheid aan God te hou...." (xx/i) en om orde en dissipline in die Kerk te handhaaf, want dit is nodig vir die opbou van die Kerk ( $x x / 2)$.

As ek dit reg interpreteer, is dit uit bogenoemde baie duidelik dat die opsig en tug die lewensverryking van die lidmaat in die oog het: Eensgesindheid en eenheid van die geloof het altyd iets goeds in die oog; veral omdat dit gaan om die geloof in Jesus Christus, ons Verlosser. Die opsig en tug wil ons verlos - dit wil nie ongegrond bind nie. Gehoorsaamheid aan God is ook nie 'n ongegronde gehoorsaamheid nie - dit is gehoorsaamheid aan die Bron van Liefde, wat met elke voorskrif altyd die goeie vir sy onderhoriges in die oog 
het. Orde en dissipline, veral as dit orde en dissipline met die oog op verlossing is, is eweneens goed bedoel.

Ons lei dieselfde gesindheid af uit die bewoording van die Bepalings wat handel oor die opsig: Op grond van die barmhartigheid van die Heer het die opsig ten doel die onderhouding van die ware godsdiens volgens die Bybel, die handhawing van die suiwer leer en dissipline en orde, om te sorg dat die Wet en Bepalings, verordenings en besluite nagekom word en om afwykings uit die weg te ruim (99). Die tug het dieselfde doelstellings as die opsig behalwe dat daarby kom dat die tug ook die suiwer lewenswandel wil handhaaf en die sakramente nie wil laat ontheilig nie (109). (Daar bestaan egter geen grondige rede waarom laasgenoemde by $99 / 1$ weggelaat moet word nie.)

Bogenoemde opvatting is 'n duidelike onderskrywing van wat Calvyn ook sê. Hy sê die tug is die Kerk se spiere - dit hou die liggaam kragtig en aanmekaar en dit voorkom dat die Kerk aan verwoesting onderworpe is. Die tug is ' $n$ toom om te bedwing, dit is 'n prikkel om die traes aan te spoor, dit is 'n vaderlike roede en 'n geneesmiddel. Die tug word gebruik in ooreenstemming met die sagmoedigheid van Christus (iv/xii/i). Die tug is vir hom 'n geneesmiddel, die fondament van orde en 'n band tot eenheid (iv/xii/2). In die lig hiervan het die tug vir hom ook positiewe doelstellings. Hy noem drie:

- Ter wille van die eer van God verhoed die tug dat ongelowiges onder gelowiges getel word. Sonder die tug kan die kerk'n samevoeging van misdadigers word.

- Deur die tug word die gelowiges (goeies) beskerm teen die verderwende invloed van die ongelowiges (slegtes).

- Deur die tug word die oortreders skaam gemaak (iv/xii:5).

Die opsig en tug is dus 'n middel waardeur die geloof in die barmhartige God bewaar moet word. Dit is nie 'n wettiese, regoristiese voorskryf en afdwing van regulasies deur 'n tiran wat ongegronde gehoorsaamheid verlang nie, maar dit het ten doel die daarstelling van 'n ruimte waarbinne die liefdesvoorskrifte van God uitgeleef kan word, wat gesê het: "Dit is nie my wil dat die mens moet sterf nie, maar dat hy hom bekeer en bly lewe" (Eseg 18:32). 


\section{DIE LEER EN LEWE VAN DIE GELOWIGE}

As daar gepraat word van die gelowige, dan word 'n bepaalde leer en lewe veronderstel. Daarvan het Paulus voor koning Agrippa getuig: Hy het vir die heidennasies gepreek oor Jesus Christus sodat "hulle tot inkeer moet kom en hulle tot God moet bekeer; en dit moet hulle bewys met dade wat by die bekering pas" (Hand 26:20).

In die Nuwe Testament is geloof altyd 'n lewensbeginsel, wat baie nou in verband staan met gehoorsaamheid. Die Bybelse teologie is woord-teologie, die woord wat mense moet hoor en gehoorsaam, waarop daar geantwoord moet word - dit vra 'n antwoord of 'n reaksie op die aanbieding van God se verlossingsaanbod. Geloof is 'n gehoorsame, persoonlike respons aan die persoonlike adres van God. Geloof is reaksie, dit is 'n daad as antwoord op God se aksie en sy daad (vgl Mt 7:24; Lk 6:47, 8:21, 11:28). Sonder verstaan èn gehoorsaam èn doen is daar in Bybelse sin gee sprake van geloof nie. Geloof het te doen met 'n persoonlike beslissing, vertroue, oorgawe en gehoorsaamheid; dit is ' $n$ heelhartige aanvaarding van God se beslaglegging op 'n mens binne sy konkrete lewensituasie met 'n gevolglike of toepaslike respons in lewe en handeling.

Hoewel geloof te doen het met besluitneming en antwoord, bly dit 'n gawe van God (vgl Ef 2:8), maar tog seker 'n gawe of 'n geskenk wat nie vir die varke gegooi kan word nie. Dit is 'n geskenk wat bewaar, gekoester en beskerm moet word en dit het ons ook gesien is die doel van die kerklike opsig en tug: die gelowige moet só gelei word dat hy nie die barmhartigheid van God verwerp nie. Geloof is nie iets wat vir eens en vir altyd op 'n bepaalde oomblik tot stand gebring of verkry word nie; dit is 'n verhouding wat in stand gehou moet word. Die Christen se ganse lewe is 'n voortdurende strewe na geloof, dit is ' $n$ "standvastige saamstry vir die geloof...." (Fil 1:27) teen die sonde.

Soos reeds opgemerk, laat ons die leer in hierdie referaat effens links en bepaal ons by die lewe van die gelowige. Hoewel geen kenner op die gebied van die Christelike etiek nie, hoe jammer dit ook al is, en ek wil waag om te sê dat dit dalk een van die fundamentele probleme by baie opsighouers van die Kerk is, wil ek tog ' $n$ paar klippe in die bos gooi en kyk wat daar uitspring.

Die mens van die twintigste eeu is besonder pragmaties ingestel. (Dit is op sigself nie verkeerd nie, behalwe as dit oorgaan in pragmatisme.) Sake wat die hoogste prioriteit geniet, is dié wat werk, wat resultate lewer - die praktiese en reële kwessies. Daarom is ' $n$ alge- 
mene vraag hedendaags: Hoe kan ek my lewe laat werk? En vir die gelowige in die besonder: Hoe kan die geloof my lewe laat werk? Juis omdat mense ingestel is op resultate wil hulle weet watter resultate gaan hulle geloof lewer.

Hedendaags kom dit taamlik algemeen voor dat mense hulle geloof (leer) en lewe van mekaar skei, veral omdat die moderne mens se lewe baie fragmentaries daar uitsien; dit is verdeel in verskillende fragmente en vir elke fragment is daar 'n ander soort etiek wat geld. In sy uiterste konsekwensie is hierdie toedrag van sake die oorsaak van skisofrenie: die verbandloosheid tussen gedagtes, gevoelens en dade. Iemand kan baie maklik 'n voorbeeldige vader aan ontbyttafel wees, 'n geslepe sakeman na $08 \mathrm{~h} 00$, 'n ontroue eggenoot tussen 13 h00 en 14h00, 'n vloekende 'n beskonke sportman na $17 \mathrm{~h} 00 \mathrm{EN}$ Sondag ' $n$ vroom ouderling by die Kerk. Nie net 'n fragmentele lewensopset lê hieraan ten grondslag nie, maar ook 'n sensuurlose verindividualiseerde samelewing, waarin feilik niemand meer iemand se hoeder is nie.

Daar is nog baie ander lewens- en wêreldbeskoulike opvattings wat mense vraagtekens oor die funksionaliteit van die geloof laat plaas. Ons dink hier aan die volgende:

- Die vryheidstrewe van die mens maak hom vyandig teenoor alle bindinge - ook die verbondenheid aan God, sy Woord en sy Kerk. Dit lei tot atëisme (vgl C Fabro, 1964, p x1i).

- Die God-is-dood-teologie. Dit is 'n verwronge poging om die ateisme vir die teologie en die gelowige nuttig en aanvaarbaar te maak (vgl JA Beukes, 1983, p 182).

- Sekularisme. Dit is die verabsolutering van sekularisasie. Dit is ook 'n bevrydingsdrang van die mens wat vir homself selfstandigheid voor God opeis (vgl JA Heyns, 1969, p 19).

- Pragmatisme. Dit is die geneigdheid by mense om eerder te vra na die praktiese funksie van 'n betrokke saak as wat hulle vra na die sinvolheid van die lewe (vgl JA Beukes, 1983, p 191).

- Mense met 'n religieuse apatie. Dit is hulle wat nie eers dink dat die geloof iets vir die mens kan beteken nie; trouens hulle dink nie eers oor die geloof nie. Dit is iets wat nie in hulle leefwêreld bestaan nie (vgl JA Beukes, 1983, p 193).

Daar is ook etlike sosiale faktore wat die moderne mens se geloof aantas, veral in dié sin dat dit ontwrigting veroorsaak in die lewens van mense. Hier dink uns aan verstedeliking en industrialisasie met 
die gepaardgaande sosiale probleme soos siektetoestande, gesinsverbrokkeling, alkohol- en dwelmverslawing, prostitusie, vereensaming, arbeidsdevaluasie, anonimiteit, onverantwoordelike vryetydsbesteding, ens. (Vgl J Verkuyl, 1979, p 192; PW Venter, HTS 145-147; IJ van Eeden, 1982, p 65; C Walsh, 1950, p 27.)

Geloof en lewe het vir baie mense so ver uitmekaargedryf dat hulle van mening is dat die geloof as ' $n$ resultaatlose aanhangsel van hulle lewens goedskiks afgewerp kan word. Hiervan is die toenemende buitekerklikheidsprobleem 'n stawende bewys.

- Statistieke van buitekerklikheid

In 1960 was $10,78 \%$ Blankes in Suid-Afrika buitekerklik.

In 1970 groei dit tot $13,93 \%$.

In 1980 ontplof dit tot 22,26 \%. (Vgl Bevolkingsensus 1970; Steekproef: Bevolkingsensus 1980.)

In die Nederduitsch Hervormde Kerk van Afrika het daar in die tydperk 1979-1981 ong 11000 lidmate vermis geraak. (Vgl JA Beukes, 1983, p 15.) In een stadsgemeente van dié kerk is daar in 1981344 lidmate opgespoor wat nie by die gemeente ingeskakel was nie (vgl JA Beukes, 1983, p 14). In die Nederduits Gereformeerde Kerk was dié kerk van 300000 lidmate minder bewus as wat op die Staatsensus verskyn het, hoogs waarskynlik omdat baie lidmate nog as lidmate bekend wil staan, maar nie soos lidmate wil lewe nie (vgl IJ van Eeden, 1982, p 13).

- Erediensbywoning

Slegs 1,05 \% lidmate van die Nederduits Gereformeerde Kerk woon meer as $40 \%$ eredienste by, $21,8 \%$ woon tussen 20 en $40 \%$ by en $77,15 \%$ woon minder as $20 \%$ by. (Vgl Agenda vir die Sesde Vergadering van die Algemene Sinode van die Nederduits Gereformeerde Kerk, Okt 1982, p 23.)

Bogenoemde statistieke is slegs die simptome van 'n dieperliggende probleem en die aktualiteit van die probleem of die rede waarom die Kerk so indringend na hierdie saak moet kyk, is gesentreer rondom die vraag of die Kerk nie self hierdie probleem aangehelp het deur die swak handhawing van die opsig en tug nie. Hier kan ons verskeie vrae vra: Het die eredienste nie leweloos geraak nie; het die ampte nie in 'n krisis beland nie; het die gemeenskap van die gelowiges nie afgewater geraak nie; het organisasie en strukture nie onfunksioneel geraak nie; het die Skrif nie dalk sy gesag verloor nie, ens, ens? (Vgl JA Beukes, 1983, p 75-175.) 'n Probleem waarop ons, 
wat hierdie referaat betref, miskien bietjie dieper op kan ingaan, is die vraag of baie lidmate nie geloof en sedes (blote lewensgewoontes in ' $n$ bepaalde omgewing) met mekaar verwar nie. Het die bediening van die doop, nagmaalsbywoning, huwelingsbevestigings, begrafnisse deur die Kerk, aflegging van geloofsbelydenis op so sewentien, agtien jaar, nie vir baie lidmate al net gewoontes (praktyke wat gesanksioneer word deur 'n bepaalde gemeenskap) geword in plaas van gemotiveerde, doelmatige handelinge, gevoed en gestimuleer deur die geloof in die Drie-enige God nie? Hiermee word daar egter nie beweer dat daar nie 'n verband bestaan tussen sedes en geloofshandelinge nie. Geloofshandelinge of -praktyke word wel sedes (gebruike of lewensgewoontes onder bepaalde mense), maar dan is dit gemotiveerde gebruike onder gelowiges, waarvan die motief die soeke na die eer van God is, wat vir sy kinders 'n goeie lewe in die oog het. Sy voorgeskrewe gebruike is lewensreëls, komende van die Bron van die lewe, dit is liefdesvoorskrifte, komende van Hom wat liefde is en nie "ons maak só omdat almal so maak nie".

Die Kerk sal in sy opsig en tug aandag moet gee aan die motiewe vir die geloofslewe. Onder gelowiges gebeur dit baie maal dat bepaalde optredes ten regte as 'n eis gestel word, maar sonder dat die motivering daarvoor gegee word. Die moderne mens wil weet hoekom hy iets moet doen. "Sommer" is nie vir hom 'n antwoord nie. Vir 'n Christelike optrede is daar altyd 'n grondige motief. Christelike sedelikheid is nie outonoom nie, dit is nie gesetel in die mens self of in sy rede nie - dit sou neerkom op elkeen maak en doen soos hy self goeddink. Juis so 'n opvatting bring 'n diskrepansie tussen geloof en lewe - wat die geloofslewe betref, maak ons soos die Bybel sê, wat ons persoonlike lewe betref, is ons outonoom. Hiermee word egter nie 'n "legalisme" gepropageer nie, nie 'n blindelingse oplê van uitwendige voorskrifte nie, maar vryheid in verantwoordelikheid geld hier.

Vryheid vra altyd verantwoordelikheid, want word vryheid onverantwoordelik gebruik, of word daarmee bedoel die gee van vrye teuels aan hartstogte en begeerlikhede, lei dit tot slawerny - slawediens aan jouself en jou begeertes, dan word dit ' $n$ drang in plaas van 'n weloorwoë optrede in ooreenstemming met die eis van die liefde - liefde vir jouself, jou medemens en God, wat 'n lewe in oorvloed bedoel. As hartstogte seëvier in 'n mens se lewe, bv dranksug, geldsug, eersug, seksuele hartstog, magswellus, ens, word jou 
lewe oorheers en jy word as slaaf uitgelewer aan iets wat die lewe verwoes in plaas van om volheid daaraan te gee.

In die moderne tyd is dit een van die probleme waarmee die kerk worstel. As massamens is die moderne mens in baie opsigte van sy verantwoordelikheid beroof - hy word geleef in plaas van om self te leef. Gevolglik beskou hy homself nie meer as aanspreeklik vir sy dade nie - die "tragiese noodlot" bestuur alles vir hom. So 'n mens het verdierlik, is onverantwoordelik, is nie meer mens in die volle sin van die woord nie. Só 'n mens is vreemd aan die Bybel. Die Bybel ken nie die mens as 'n "slagoffer" nie, maar as iemand wat "aandadig" is, wat "skuld" het waarvoor hy verantwoordelik is.

Hierdie Bybelse siening van die mens verkleineer nie die mens of dryf hom in ' $n$ hoek nie, maar gee waarde aan die mens; dit is 'n seën vir die mens. ' $n$ Mens wat nie meer verantwoordelik is nie, het sy waarde as mens verloor.

Die funksie van die opsig en tug is om die mens tot verantwoordelikheid te roep, met ander woorde, dit gee die mens sy waardigheid terug wat hy dalk besig was om te verloor deur onverantwoordelik en "onchristelik" op te tree. Oproep tot verantwoordelikheid is oproep tot liefde. Liefde is die beginsel vir waardigheid, geborgenheid en sekuriteit, en dit is gelyk aan lewe. Dit is Christus se nuwe weg (vgl Heb 10:20), dit reinig van skuldige gewetens (10:22). Daarom moet ons na mekaar omsien (pastoraat) deur mekaar aan te spoor (opsig) tot liefde en goeie dade (10:24). Interessant genoeg is dit ook die motivering vir die getroue opgaan na die erediens (10:25).

Met alles wat tot dusver onder punt 3 genoem is, wil ons net onderstreep dat die Kerk al sy meganismes goed geölie moet kry om te verhoed dat daar nie by sy lidmate ' $n$ diskrepansie begin ontstaan tussen geloof en lewe nie, want die egte geloof in die Drie-enige God is allermins iets wat buite die lewenspraktyk kan staan. Geloof is lewe. Geloof bepaal 'n mens se handelinge, sy gedrag, sy doen en late - soos 'n mens glo, so is hy en so leef hy.

Juis die feit dat geloof 'n aanhangsel tot baie mense se lewens geword het, het aanleiding daartoe gegee dat hulle op ander plekke na iets gaan soek het wat bestendigheid aan hulle konkrete lewe kon gee, want hulle is miskien geleer of beïnloed of selfs verkeerdelik deur gelowiges voorgegaan dat geloof nie ook 'n praktiese saak is vir die lewe van elke dag nie - dit is net gereserveer vir Sondae tussen 09 h00 en 10 h00. Die gevolg van so 'n opvatting is dat daar met die 
lewe geëksperimenteer word. Slaag die eksperimente nie, word die lewe selfs verag en dit gee aanleiding tot slordige lewens (verslawing, selfmoord, seksuele losbandigheid, ens). As sulke mense die tydelike lewe minag, het hulle in die meeste gevalle ook geen perspektief op die ewige lewe nie. Daar word so min van die lewe gedink en verwag dat daar ook maar geredeneer word: Laat ons eet en drink, want môre sterf ons.

\section{SLAAG DIE OPSIGHOUERS IN HULLE DOEL?}

Uit die voorafgaande blyk dit dat die opsig en tug gegrond is in die barmhartigheid van God self. Barmhartigheid, veral God se barmhartigheid, het altyd 'n sinvolle, vrugbare, goed gedissiplineerde en op liefde gerigte lewe in die oog. So ' $n$ lewe is volgens die Bybel alleen moontlik as daar ' $n$ hegte verbondenheid bestaan tussen God en die mens. Neem 'n mens die lewensgesteldheid van baie lidmate en veral die band wat bestaan tussen hulle en God in aanmerking, wil dit voorkom of die Kerk deur sy opsig en tug nie die ter sprake barmhartigheid kon verkonkretiseer nie. Daarom moet ons die opsighouers van die Kerk vir' $n$ wyle onder die vergrootglas plaas.

Volgens die Kerkwet en Bepalings van die Nederduitsch Hervormde Kerk van Afrika (xx en 99-103) is die subjekte van die opsig en tug die lidmate, ampsdraers en vergaderings van die Kerk. Hoewel lidmate in artikel $\mathrm{xx}$ en bepaling 99 genoem word as subjekte van die opsig en tug, word daar nie oor hulle uitgebrei of weer na hulle verwys in bepaling 100 waar daar gehandel word oor die opsighouers nie. Myns insiens is dit beslis ' $n$ tekortkoming.

In bepaling 100 word gestel dat die kerkraad opsig hou oor lidmate en ampsdraers van die gemeente, die ringsvergadering en ringskommissie oor gemeentes, predikante, professore en ander dosente en ouderlinge en diakens wat in die ringsgebied val, en die Algemene Kerkvergadering en Kommissie van die Algemene Kerkvergadering oor die ringsvergaderings en organe van bystand.

Bogenoemde ampte, vergaderings en kommissies hou opsig deur aan te moedig, raad te gee, te waarsku, tereg te wys, te bestraf en voorligting en advies te gee deur middel van gesprekvoering tydens huisbesoek of tydens geleenthede waartoe lidmate, ampsdraers, ens opgeroep word. By gebrek aan positiewe reaksie word die tug toegepas.

Kyk 'n mens na die "opsig- en tugmasjienerie" van die Kerk en na die manier waarop hierdie masjien behoort te funksioneer, lyk dit of 
daar nie maklik hierop verbeter kan word nie, maar kyk 'n mens na die resultate, begin 'n mens dadelik te wonder. Aangesien die opsig en tug die spiere is waarmee die Kerk aanmekaar gehou behoort te word, wil 'n mens tot die konklusie kom dat die spiere verslap het, gemeet aan die deformasie waarmee die Kerk huidiglik worstel. As die fout nie op die "teoretiese" vlak lê nie, moet ons iewers anders gaan soek. Potensiële sterk spiere is nie noodwendig bruikbare spiere nie. Dit moet eers geoefen, met ander woorde opgelei word. Potensiële sterk, geoefende spiere is ook nie vanselfsprekend bruikbaar met die oog op 'n spesifieke doel nie: Dit kan soms doodslaan in plaas van om in liefde te beskerm en te bewaar. Daar kan met ander woorde 'n gesindheidsprobleem wees.

As ons tevrede is met die uiteensetting van die opsig en tug in die Wet en Bepalings van die Kerk, met ander woorde as dit ons insiens potensiële sterk spiere is, èn daar is nog steeds buitengewone deformasie, bly die liggaam nog steeds siek en gaan van kwaad na erger (dalk alreeds ' $n$ "terminale pasiënt"), dan skyn die probleem moontlik 'n toerustings- en gesindheidsprobleem te wees. Aangesien die opsig en tug gegrond is in die barmhartigheid van God, aangesien sy barmhartigheid en liefdesgesindheid teenoor die mens deur die opsig en tug uitgedruk word, is ek van mening dat die gebrek aan goeie gesindheid een van die grootste probleme is. Om gesindhede wetenskaplik te bepaal, is nie altyd so maklik nie, veral nie as dit dwarsoor die hele Kerk gedoen moet word nie. (Die Raad vir Prediking en Erediens met die moontlike samewerking van die RGN, is tans besig met so 'n ondersoek.) Klagtes oor swak gesindhede gaan gewoonlik op hoor-sê (soms met 'n geskinder daarby!). Gesindhede is meestal spontane optredes wat nie formeel wetenskaplik getoets kan word nie, maar tog gaan daar 'n rokie op as ons kyk na die Wetenskaplike Bydraes van die PU vir CHO, F3/12, getitel: VENSTER OP DIE KERK, waarin twintig lidmate oor die reformasie van die kerk in die jare tagtig praat.

Ons het reeds aangetoon dat die opsighouers die lidmate, ampsdraers en vergaderings van die Kerk is. Bogenoemde publikasie van die PU vir CHO sê die een en ander oor die toerusting en gesindhede van opsighouers.

\section{Lidmate}

Dit grootste skare van onbenutte kragte in die Kerk is die lidmate self. Die krag van die Kerk lê in sy lidmate, want die 
Kerk is sy lidmate. Hulle is die getuies van Christus, hulle is God se vertoonkas deur wie Hy wys hoe versoende mense leef. Die lewe van die gelowige is een van die belangrikste opsigmiddels, dit is die voorbeeld van wat behoort en wat behoort nie.

Die eerste gesindheidskrisis by die lidmaat ontstaan omdat die lidmaat nie meer weet waar hy inpas "in die kerk van dominees en ouderlinge en diakens" nie (Venster op die Kerk, 1980, p 131). Die lidmaat voel homself taakloos, terwyl ons tog altyd praat van die amp of die taak van die gelowiges.

Ons gaan hier slegs 'n paar probleme probeer identifiseer:

(a) Die erediens: Lidmate is in 'n hoë mate passasiers in die erediens. Hoewel hulle in "teorie" deelneem, is baie in die "praktyk" passief. Hulle word nie werklik in die geloof só gebou en versterk in die geloof dat hulle vanuit die geloof kan beoordeel, leiding gee en vermaan indien nodig nie. Hulle kan ook nie altyd as gevolg van hulle "belewing" van die erediens ander "aanmoedig" om daarheen te gaan nie (vgl Heb 10:25b).

(b) Gemeenskap van die gelowiges: As gevolg van die moderne gees van individualisme bly baie gemeentelede vreemdelinge vir mekaar. Die gevolg is dat die "onderlinge vermaning en bemoediging uitbly, want bemoedigende vermaning kan slegs plaasvind waar daar 'n vertrouensverhouding is" (Venster op die Kerk, 1980, p 132).

Sodoende val die "lewensnoodsaaklike ondersteuning weg", wat ons almal eintlik nodig het om in gemeenskap met God te bly lewe. Die ware gemeenskap met God, veral in die erediens, behoort (as dit reg beleef word) die gemeenskap met die medemens tot stand te laat kom. Die gevolglike gemeenskap met die medemens stimuleer die lewe sodanig dat daar weer ' $n$ begeerte terug na die erediens behoort te wees.

Die gebrek aan die gemeenskap van die gelowiges is dus een van die hoofredes waarom lidmate aan 'n "taak- of funksieverlies" ly, veral wat hulle opsigtaak betref.

Wat sou die redes vir hierdie probleem wees?

(i) Die besondere ampte versmoor en verwring die taak van die gelowige, terwyl dit juis gestimuleer moet word (vgl Ef 4:12v). Hierdie fout word op die rekening van beide die lidmaat en 
die ampsdraer geplaas. Die ampsdraer is heerssugtig en voel bedreigd as die lidmaat iets wil doen. Lidmate is soms weer van mening dat ampsdraers ' $n$ plaasvervangende funksie beklee en alles namens hulle moet doen - dit is baie maal ' $n$ handige verskoning vir gemaksugtigheid.

(ii) 'n Tweede oorsaak vir hierdie probleem kan 'n ondoelmatige kerklike bediening wees. In plaas van toerusting vir onder andere taakuitvoering, is die prediking, kategese en pastoraat in baie gevalle net 'n oproep tot die eerste stappe van die geloof. In plaas van om vir die gelowige ook uit te spel hoe om as gelowige te gaan leef, word daar net verkondig hoe om tot die geloof te kom of net die feit gekonstateer dat hy moet glo, maar nie hoe hy moet glo nie.

(iii) 'n Saak wat met die voorafgaande saamhang, is dat daar in die kerklike verkondiging, veral soms in die erediens, 'n "tale Kanaäns" gebruik word. Die taal wat ons praat, is soms so vreemd van die gewone alledaagse Afrikaans, dat lidmate gevolglik ook dink dat die verkondiging en die gebede nie iets te sê het vir sy alledaagse lewe nie. Dit bring mee dat lidmate nie as "broeder se hoeder" oor geloofsake kan gesels nie, want hulle het nie verstaan hoe hulle dit moet gaan doen nie, of hulle probeer dit wel doen, maar dan ook in die vreemde Afrikaans waarin hulle dit gehoor het, met die gevolg dat hulle boodskap ook niksseggend bly.

(iv) Die gebrekkige eksistensiële betrokkenheid van ampsdraers by dit wat hulle verkondig of toesien dat dit verkondig word, laat die gedagte by lidmate dat 'n mens nie nodig het om uit te leef wat verkondig word nie.

(v) Swak toegeruste ouderlinge en diakens skep die indruk by lidmate dat hulle nog swakker toegerus hoef te wees. As die ouderling nie eers kan vermaan en vertroos en bemoedig nie (hy gaan roep altyd die dominee), hoe kan daar verwag word dat lidmate dit moet doen?

(vi) By baie lidmate bestaan daar ook 'n gebrekkige versoeningsbegrip en -belewing. As gevolg van allerhande skuldgevoelens omdat hulle glo dit kan nie vergewe word nie, word lidmate verhinder om hulle koppe uit te steek. Hulle wil nie eers gesien word nie, wat nog daarvan om ander te vertroos en te vermaan. 
(vii) Hoewel die Kerk met behulp van KITAL baanbrekerswerk doen met die oog op voortgesette kategese of Bybelstudie, is daar baie gemeentes waarin hierdie saak verwaarloos word. Die grootste probleem wat ondervinding mens leer, is dat baie lidmate self onder ' $n$ wanindruk verkeer. Hulle is van mening dat as jy klaar gekatkiseer het, is jy klaar. Dan is dit jou voorreg om passasier te word. Bybelstudiegeleenthede is dié geleenthede wat hulle by uitstek daartoe leen om ook vir lidmate uit te spel hoe om hulle geloof in hulle alledaagse lewe te verkonkretiseer, die saak waarna ons ook in (ii) verwys het. Dit versterk ook die gemeenskap onder gelowiges.

(viii) 'n Gemaksugtige, materialistiese en individualistiese tydsgees ry ook die gemeenskap van die gelowiges in die wiele en skep 'n gesindheid van ons-gee-nie-meer-vir-mekaar-om-nie. Elkeen sit met sy eie boekie in sy eie hoekie, het nie meer tyd vir ander en vir die kerk nie én ontwerp vir sy eie "hoekie-lewe" 'n ander etiek as dié wat geld onder gelowiges.

\section{Ampsdraers}

Hier gaan nie 'n Skriftuurlike ampsbeskouing voorgehou word nie, maar daar gaan hoofsaaklik gekyk word na 'n moontlike toerustingsen gesindheidsprobleem by ampsdraers.

\section{(a) Die predikante}

Een van die bydraes in Venster op die Kerk is getitel: "Dominee: Dienaar of dominant?" (p 87). Hiermee wil die skrywer dit duidelik tuisbring dat ' $n$ predikant moet dien en nie moet heers of domineer nie.

Om te kan dien, het die predikant deeglike toerusting nodig. As daar een beskuldiging is wat ons nie moet waag om aan die adres van predikante te rig nie, dan is dit dat hulle nie toegerus is nie. So teologies-wetenskaplik as wat kan kom, so intensief soos nog nooit tevore nie, so absoluut akademies word hulle toegerus, maar nou is die vraag: Het daar nie iets van die predikant as mens by sommige verlore gegaan nie? Het hierdie hooggeleerdheid en die vermoë om die hoë woorde uit te spreek nie meegebring dat hy as die enigste kenner op sy vakgebied in die gemeente wil domineer in plaas van om te dien nie? Praat hy nie op sy hoogdrawende, geleerde manier by mense verby nie? Daar word gepraat van die Sosiologie, Psigolo- 
gie en Kommunikasiekunde as hulpwetenskappe vir die Teologie. Moet ons nie ophou om net te sê dit het 'n hulpverlenende funksie en daadwerklik van die hulp gebruik begin maak nie, sodat die predikant mens kan bly onder mense?

Wat, sou 'n mens kon vra, het dit te doen met die opsig en tug? Juis omdat die opsig en tug nooit in dieselfde asem met heers en domineer genoem mag word nie, het dit alles daarmee te doen. Opsig en tug het te doen met geloof, met lewe, met mens-wees, met gelowige mens-wees in die konkrete lewensituasie. Daarom moet die predikant kennis dra van die totale mens. Omdat al die verkondigingsgestaltes ' $n$ opsigelement bevat, moet die predikant in staat wees om die inhoud van sy boodskap (dit waarvoor hy akademies so goed geskool is) reg en suiwer by die adres te laat uitkom. Ons sou wel kon sê dat die predikant tog 'n kind van sy tyd is en dat hy op die hoogte behoort te wees van alle samelewingsverskynsels en psigiese gesteldhede van sy tyd. Dit mag by baie wel die geval wees, maar tog kan daar ook baie van diegene wees wat die verkeerde kind van sy tyd is, sonder die nodige evalueringsvermoë en sonder die nodige diskresie om die Woord ' $n$ dienende funksie te laat beklee in die lewe en omstandighede van bv ' $n$ ontspoorde wat bemoedig, vertroos of gewaarsku moet word.

Die predikant moet in staat wees om sy "hooggeleerdheid" prakties in diens van die gemeente te stel. Gemeentelede het nou maar eenmaal klagtes, kwellinge, "geestelike" siektes, vreugdes, blydskap, ens. As opsighouers is dit die taak van predikante om in al hulle verkondigingsarbeid die hand op die pols van die gemeente te hou (diagnoseer), en om nie die pols te gaan dokter nie, maar die hart. Dit is baie predikante se probleem: Hulle kan goed diagnoseer, maar weet nie hoe om te genees nie - miskien omdat hulle "onmenslik" geword het. "Die onderbeklemtoning van die menslikheid van die prediker, gee daartoe aanleiding dat hy as unieke 'spesie' geïsoleer word van sy medemens" (HJP Venter, 1984, p 12).

Hierdie probleem moet ook gesien word van die lidmaat se kant. As die lidmaat die predikant as "iets" onmenslik beskou, gaan dit baie moeilik wees vir die predikant om deur te dring tot in die lewe van die lidmaat, veral in sy pastorale werk. Die bedoeling van die pastoraat is juis dat die predikant sal "inkom" in die konkrete lewe van die lidmaat, maar nou gebeur dit juis dat die lidmaat "toeslaan" sodra die predikant sy opwagting maak. In plaas van in die konkrete lewe inkom, tref die predikant 'n kunsmatige situasie aan. 
Hier kan ons ook verwys na enkele opmerkings van JI de Wet (vgl HTS, 30:3 en 4:112vv). Hy sê dat daar 'n groot afstand bestaan tussen die "opleidingsideaal en die eindresultaat" by die opleiding van predikante. Hierdie leemte, sê hy, het twee bestanddele. Dit is die kwessie van akademiese geskooldheid en persoonlike ingesteldheid. Gebeur dit nie soms dat die bes "gekwalifiseerde" predikant sy "apparaat" links laat wanneer hy in die bediening staan nie? Hierdie linkslaat van die teologiese geskooldheid is in meeste gevalle te wyte aan 'n gebrek aan verantwoordelikheid, miskien kan 'n mens dit ook luiheid noem. Dit is met ander woorde' $n$ gesindheidskwessie. Om oor gesindheid te praat, is altyd 'n moeilike saak "want dit kan so maklik ontaard in ' $n$ sieklikheid of misverstaan word as 'n habitus, as een of ander selfgemaakte hebbelikheid" (HTS, 30:3 en 4:113). Predikante is nie 'n klomp vroomdoeners nie, maar reggeaarde evangeliedienaars wat die gemeente liefhet omdat hulle die Here liefhet. Volgens die Bybel het 'n predikant geskooldheid en gesindheid nodig. "Albei is in die regte hoeveelheid en verhouding nodig omdat hulle mekaar van vervalsing en afwyking bewaar ...." (HTS, $30: 3$ en $4: 114$ ). In 'n ander artikel (HTS, 25:1:11-20), gee De Wet 'n rede aan waarom hierdie probleem myns insiens bestaan. Hy sê dat daar skynbaar nie genoeg aandag gegee word aan die pastorale etiek by die opleiding van predikante nie en gevolglik weet 'n predikant nie altyd wat die etiese implikasies en eise van die ampsbediening inhou nie.

\section{(b) Die ouderling}

Die ouderlinge is die "opsieners" van die gemeente, met ander woorde die eintlike opsighouers. Dit bring ons by die dringendheid van die ouderlingskap. Steenberg sê dat die beeld van die "snorkende ouderling" in 'n boek van Jan Rabie verduidelik hoe daar oor die ouderling gedink word (vgl Venster op die Kerk, 1980, p 97).

Dit is 'n aanklag teen die ouderling en teen die kerk. Hy sê dat baie van die bekleërs van hierdie belangrike amp "maar staan en toekyk dat dinge in die gemeente maar aangaan en gedoen word". Daar is baie vrae, sê hy, wat aan die ouderling gerig kan word: Hoe dikwels besoek hy sy wykslede en wat doen hy tydens sy besoeke? Hoedanig is sy prioriteite - kom sy wykswerk eerste naas ander aktiwiteite? Stel hy soveel in kerksake belang dat hy sy wykslede ook motiveer om dit te doen? Of is hy slegs iemand wat so nou en dan 'n pligsbesoekie doen en 'n paar formele vrae vra? En hoedanig is hy toegerus vir sy taak? 
In die taal van ons Kerkwet en Bepalings: Kan die ouderling werklik 'n woord van bemoediging, raadgewing, waarskuwing, teregwysing, bestraffing, advies en voorligting spreek met die toerusting wat hy tot sy beskikking het? Een van die groot krisisse waarin die ouderling hom bevind, is die feit dat hy beskroom staan teenoor die teologiese kennis van sy geleerde leraar en hom net laat lei deur sy uitsprake. Waar die kortsluiting by die predikant se opsigtaak heel waarskynlik sentreer rondom gesindheidskwessies en 'n gebrek aan diskresie om sy geleerdheid of toerusting prakties te maak, sentreer dit by die ouderling meer rondom die toerusting. Van predikante word verwag dat hulle ses jaar en meer intensief akademies geskool moet word, terwyl ouderlinge tevrede moet wees om in meeste gevalle met ong 'n uur se kategese te volstaan. Ons behoort ons hoede vir ons ouderlinge af te haal dat hulle kans sien om met so 'n gebrekkige toerusting alles te doen wat van hulle verwag word in artikels 167 en 168 van die Kerkwet en Bepalings. Of weet baie dalk nie eers wat in die betrokke artikels staan nie? Wat word daarin van die ouderling verwag? Hy moet toesien dat eredienste bygewoon word, dat die nagmaal gebruik word, dat kinders gedoop word, sorg dat die Woord reg en gereeld bedien word, opsig hou oor die leer en lewe van die predikant en oor gemeentelede; hy moet buitekerklikes bearbei (dink maar aan al die argumente van meneer Amptenaar, mejuffrou Sake, professor Akademie, doktor Evolusie en meneer Baas wat hy moet kan hanteer - vgl Venster op die Kerk, 1980, p 98), herderlike sorg doen, kinders, jongmense en buitekerklikes katkiseer en die jeug geestelik vorm. Hy moet die Bybel ywerig bestudeer, lidmate wat in beproewing verkeer of moeite en probleme in die gesinslewe ondervind, besoek en ondersteun, ens, ens.

Wat 'n pragtige, ideale en goeddeurdenkte "proses-en-taakontleding", maar hoeveel daarvan kom tereg en hoeveel is prakties moontlik vir die deursnee ouderling in ons gekompliseerde samelewing? Hoe word die ouderling hiervoor toegerus of is die dominee maar weer die kenner by wie die ouderling verleë om hulp moet gaan aanklop? Is hierdie toedrag van sake nie een van die oorsake waarom daar so 'n nypende tekort aan ouderlinge is nie? Eise word aan mense gestel waartoe hulle nie in staat is nie. "Die beeld van die ouderling in die gemeente en gemeenskap sê so dikwels dat die munt van die ouderlingskap gedevalueer het. Met hoeveel? Met vyf persent, met tien persent? Ek vrees, met eerder nader aan tagtig persent in baie gevalle! Dit is een van die redes waarom ouder- 
lingsbanke leegloop; en die beeld van die ouderling lok nie nuwe kandidate nie" (Venster op die Kerk, 1980, p 98). Hierdie toedrag van sake maak van die ouderling 'n toeskouer wat bou aan 'n toeskouersgemeente.

Lidmate wat nie meer met hul ganse lewe betrokke is by kerksake nie, is die hoofonderwerp vir die referate by hierdie vergadering. Dit is ons kommer en ons gevolgtrekking as ons die kerkvolk gadeslaan. As die primêre opsighouers, die voorbeeldstellers en die regeerders self staan en toekyk, sál almal later ook net staan en kyk. Die "voorganger" van die gemeente hou die instrumente in sy hande om te bou of af te breek, om te versamel of te verstrooi, die getuienis te laat klink of te verstom. As hy dit laat val, is ruïnes, verstrooiing en 'n doodse stilte die voorland van die Kerk.

Opsig en tug het te doen met lewe, met die gesond hou van die gemeente sodát dit kan lewe; dit het te doen met meelewe, dit is die spiere wat die gemeente kragtig en beweeglik moet hou. Nou vra Steenberg of die ampsversuim by die ouderling en die leraar nie dikwels die rede is waarom die tughandeling agterweë bly nie. "Dit is in sy opsig oor belydenis en wandel van die gemeente dat die ouderling verstar het, en dit is in hierdie verband dat opsieners weer dringend moet besin" (Venster op die Kerk, 1980, p. 101).

Die grootste seer wat Steenberg oopkrap, is die van die verhouding ouderling/leraar. Die ouderlingsamp is ingestel om die leraarsamp aan te vul. Die leraar het die opsig van die ouderling nodig. Dit is die broederlike meelewing en onderskraging van die ouderling. Juis omdat predikante voortdurend in die bediening moet gee, het hulle die geestelike gesprek van die ouderling die meeste nodig. Hoekom moet hulle die voorregte van 'n gewone lidmaat ontbeer? Of is predikante dalk bang dat ouderlinge in hulle lewens betrokke raak en hou hulle hulle gevolglik so ver as moontlik op 'n afstand?

\section{(c) Die diaken}

Hier het ons ook met 'n toerustingsprobleem te doen, maar nie so erg as by die ouderling nie, want die diaken se hande word in 'n groot mate ondersteun deur diakonale organe van bystand (vgl bepaling 177 van die Kerkwet en Bepalings) wat onder andere professionele dienste lewer en deur die staat en welsynsorganisasies wat sorg vir pensioene, welsynsdienste ens, ens.

Die dilemma van die diaken is egter dat die armes, die sosiaalontwrigtes en die bejaardes nie meer direk voor sy deur staan nie- 
hulle word absoluut professioneel versorg; die siekes is op dominee se rekening en die wat oorbly, kan maar deur die diensgroepe versorg word. Dit bring mee dat die diaken in 'n groot mate bedreig, beledig en gedegradeer voel. Hy word gesien as 'n blote geldversamelaar.

Feit bly egter dat die diaken opsig moet hou en verantwoordelikheid moet aanvaar met betrekking tot die barmhartigheidsdiens. Hiermee is hy egter soort van in 'n hoek gedryf. Daarom moet daar gekyk word of die diaken nie 'n taak het wat wyer lê as armversorging en die oplossing van "slagoffer-probleme" nie.

Ons het gesien dat die opsig en tug ook te make het met die goeie orde en dissipline in die gemeente. Hoe teologies korrek dit is, is 'n vraag wat ons nie hier gaan beantwoord nie, maar die feit bly dat die diakensamp in die Kerk gegrond word op Handelinge 6.

In die gemeente van Jerusalem het daar wanorde gekom - die gemeenskap is bedreig as gevolg van 'n murmurering wat ontstaan het omdat sommige weduwees in die daaglikse versorging oor die hoof gesien is. Ons kan nie sonder meer aanvaar dat die "daaglikse versorging" waarvan hier sprake is, slegs te doen het met armversorging nie. In die Grieks is daar sprake van daaglikse diakonia, waaronder verstaan word ' $n$ saamkom van almal, ' $n$ betrokkenheid by mekaar. Op grond hiervan, sê Coetzee, het die barmhartigheidsdiens in die Nuwe Testament te doen met die gemeenskaplike versorging, met die gemeenskap van die heiliges as heersende motief (vgl JC Coetzee, 1981, p 68). Wat is hierdie "gemeenskap"? Dit is deel hê aan iets van iemand anders, aandeel hê in sy smart of vreugde, saamleef met hom en deelname gun aan iets wat jy het. "Armversorging" is nie 'n saak op sigself nie - dit is 'n uiting van die groot saak, naamlik die ware saamlewe, die liefdesgemeenskap van die kinders van God. Coetzee sê dat die roeping van die diaken hierin lê dat hy in die gemeente van Christus die diens van die konkrete belewing van die liefdesgemeenskap tussen kinders van God mag onderhou, bevorder en uitbou. Dit sluit ook die versorging van die armes en die ontwrigtes in, maar slegs as deel van die ampsroeping.

Dit los die probleem op van die diaken wat met ledige hande staan. Dit gee hom 'n aandeel in die opsigtaak in die gemeente, dit laat hom deurdring tot in die konkrete lewe van die gemeentelid. Nou is sy werk nie meer (soos dit in die praktyk geword het) om net van huis tot huis geld te kollekteer nie, maar om van huis tot huis uit te vind hoe dit met die gemeentelede gaan, wat hulle vreugdes en 
wat hulle klagtes en wat hulle node en wat hulle seëninge is. So sal die gemeentelid ook weer sien dat die Kerk vir hom omgee, dat die Kerk opsig oor hom uitoefen - nie net om hom te straf as hy hom misdra nie, maar ook om hom op te help as hy val.

\section{Die vergaderings}

Volgens die Wet en Bepalings van die Nederduitsch Hervormde Kerk van Afrika hou 'n kerkraadsvergadering opsig oor die lidmate en ampsdraers van die gemeente, die ringsvergadering en ringskommissie oor gemeentes, predikante, professore en ander dosente en ouderlinge en diakens in die ringsgebied, en die Algemene Kerkvergadering en die Kommissie van die Algemene Kerkvergadering oor ringsvergaderings en organe van bystand. Bogenoemde vergaderings en kommissies verrig hulle opsigtaak deur diegene met wie hulle 'n gesprek wil voer, skriftelik op te roep (vgl Bepaling 100). In bepalings 101-128 word die wyse van opsighouding redelik deeglik omskryf.

In die lig van dit wat in 2 hierbo gesê is, bestaan daar 'n groot leemte in die omskrywing van die opsigtaak van die vergaderings en hulle kommissies. Die opsig oor ampsdraers adem eerder ' $n$ gees van regorisme en formeel amptelike handelinge as wat dit 'n uitdrukking is van die barmhartigheid van die Heer van die Kerk. Verslae word behandel, leer en lewenswandel word gekontroleer en slegs in gespanne verhoudings (Bepaling 104) word aandag gegee aan besware, beklagings of klagtes.

Opsig en tug is nie net 'n geneesmiddel nie - dit is ook die spiere wat gesond, geoefen en doelmatig gehou moet word. Dit is nie net om die verbroke eensgesindheid en eenheid van die geloof te herstel nie, dit het ook 'n bevorderings-, bewarings-, en handhawingsaspek, dit wil nie net terugbring nie, dit wil ook behou, dit is ook evangelie wat beide kante van die tweesnydende swaard gebruik.

Aangesien die opsig en tug ' $n$ deel uitmaak van al die verkondigingsgestaltes, veral van die pastoraat, is die sielesorg aan die sielsorger, die opsig oor die opsighouers absoluut noodsaaklik. Die rede hiervoor is die volgende: Nasorg is ook altyd voorsorg - dit verrig voorsorg deur lewensordening. "En juis in verband met hierdie ordening van die lewe ... vervul die opsig en die tug hulle onmisbare funksie in die Kerk (vgl JI de Wet, HTS, 22:2 en 3:43) Opsig en tug is nie los "appendices" van die kerklike verkondiging nie. 
"Huisbesoek wat goed en reg gedoen word, is as woordverkondiging, dit wil sê, as onderrigtende nasorg wat voorsorg tref vir die ongehinderde voortgang van die evangelie, opsighouding en tug. Anders gesê: Die Kerk kan eers dan werklik opsig hou en met 'n skoon gewete tug uitoefen as sy huisbesoek werklik huisbesoek is" (JI de Wet, 22:2 en 3:44).

In die lig van hierdie uitspraak behoort daar uitgebrei te word op dié bepalings van die Kerkwet wat handel oor die opsig van die ringsvergadering, die Algemene Kerkvergadering en hulle kommissies. Hier moet voorsiening daarvoor gemaak word dat ampsdraers beter opsig oor mekaar uitoefen deur meer betrokke te raak by mekaar en nog nader bepaal: Lede van ringskommissies (nie noodwendig net die voorsitter nie) behoort op 'n gereelde basis huisbesoek te doen by ringspredikante, en gemeenteouderlinge om die beurt by mekaar. Daar is baie predikantsgesinne wat ook weer die voorreg van 'n gewone lidmaat wil geniet deur 'n predikant vir huisbesoek te ontvang, en ouderlingsgesinne wat graag 'n ouderling op huisbesoek wil hê. Hierdie tekortkoming het vir hulle wat die swaarste trek in die Kerk se juk en by wie daar moontlik legio frustrasies bestaan, ontneem van die voorreg om ook bemoedig, vertroos en selfs vermaan te word. Baie klagte en besware teen predikante kon vermy gewees het en baie ampsfrustrasies by kerkraadslede en predikante uit die weg geruim gewees het èn die Kerk sou eers dan werklik opsig (ge)hou (het) en met 'n skoon gewete tug uit-(ge)oefen het as sy huisbesoek werklik huisbesoek was. Ons het reeds vroeër gesê dat die "onmenslikheid" van predikante 'n muur bou tussen hulle en hulle lidmate. Die "onmenslike" optrede teenoor predikantsgesinne, veral in dié opsig dat die pastoraat nie behoorlik teenoor hulle beoefen word nie, het in baie gevalle seker ook al 'n muur gebou tussen predikantsgesinne en die Kerk. Hoe hard en miskien onbewysbaar dit ook al mag klink: Baie predikante sit eerder 'n geskinder oor 'n kollega aan die gang en skrik hulle kwansuis boeglam as ' $n$ klag teen hom ingedien word, in plaas van om die barmhartigheid van God deur hulle te laat spreek en so 'n kollega te hulp te snel.

As ons 'n kerk wil hê met lidmate wat gesond is in leer en lewe, moet ons ons daarvoor beywer dat ons ampsdraers ook in dié opsig gesond sal wees. 


\section{WAT MOET GEDOEN WORD OM DIE OPSIG/TUG TE VERBETER?}

Die ampstruktuur van die Kerk is iets waarop daar nie maklik verbeter sou kon word nie. Of die moontlikhede wat hierdie struktuur bied tot sy volle potensiaal benut word, is ' $n$ ander vraag. Sonder om op volle besonderhede in te gaan, gee ons hier enkele rigtingwysers oor hoe die ampstruktuur moontlik beter tot sy volle potensiaal kan kom. Dit is alles sake wat ons etlike kere al gehoor het, maar waaraan daar nie daadwerklik aandag gegee word nie.

In hierdie referaat gaan dit oor die lewe van die gelowige: Efesiërs 4, is dié hoofstuk wat handel oor die lewe van die gelowige: "Laat julle lewenswandel in ooreenstemming wees met die roeping wat julle van God ontvang het. Wees altyd beskeie, vriendelik en geduldig, en verdra mekaar in liefde" (Ef 4:1b, 2). Om so 'n lewe moontlik te maak, is daar bepaalde "gawes" gegee, naamlik: "apostels, profete, evangeliste, herders en leraars. Sy doel daarmee was om die gelowiges toe te rus vir hulle diens en vir die opbou van die liggaam van Christus" (Ef 4:11b,12). Uit die voorafgaande het ons gesien dat die simptoom wat ons tot kommer stem die agteruitgang of deformasie van die liggaam van Christus is. Ons het gediagnoseer dat swak gesindhede en ondoelmatige toerusting die groot oorsaak van hierdie kwaal is. Die behandeling wat nodig is, is om die "gawes", of soos ons sê, die ampte of die ampstruktuur, weer op datum te kry.

- Lidmate moet weer toegerus word om opsig oor mekaar uit te oefen. Hulle moet geleer word dat hulle nie toeskouers of passasiers in die gemeente is nie, maar die eintlike mense wat dienswerk moet gaan verrig, veral om "mekaar aan te spoor tot liefde en goeie dade". Lidmate mag nie ledig staan naas werkende ampsdraers nie.

In al die verkondigingsgestaltes moet lidmate toegerus word vir taakuitvoering en nie slegs opgeroep word tot geloof nie. Nie net die "wat" van die geloof nie, maar ook die "hoe" van die geloofslewe moet in 'n verstaanbare taal uitgespel word. Hier moet die Kerk veral daaraan dink om beter toerusting aan lidmate te gee in die Christelike etiek.

Om die reeds belydende lidmaat toegerus te hou, is "opvolgkursusse" in die kategese onontbeerlik - ons noem dit voortgesette kategese of Bybelstudie. Kerkrade wat hierdie saak verwaarloos, het 'n rekening te betaal aan hulle beskroomde lidmate, wat met 
dié verleentheid sit dat hulle weet hulle moet iets doen, maar nie weet hoe om dit te doen nie.

\section{Ampsdraers}

Predikante:

Die beginsel dat predikante moet dien en nie heers of domineer nie, maak dit noodsaaklik dat ons in die opleiding van predikante miskien meer aandag aan die pastorale etiek moet gee om beter gesindhede by predikante aan te leer.

Die opvatting wat by sommige predikante bestaan dat die mens nie ook belangrik is in die verkondiging van die evangelie nie, is 'n argument wat net nie opgaan nie. Die "nuwe wetenskappe", soos die Antropologie, Psigologie, Sosiologie, Dieptepsigologie, Kommunikasiekunde en Opvoedkunde is nodig om die evangelie effektief te verkondig (vgl MJ du P Beukes, 1982, p 58; B Häring, 1974, p 10; WJ de Klerk, 1974, p 3v). Dit is so dat die beoefenaars van hierdie wetenskappe nie altyd gelowiges is nie, maar dit maak nie die resultate van hulle ondersoek onbruikbaar nie. As ons erns wil maak met die oorkom van ons boodskap, sal ons ook erns moet maak met die mens aan wie die boodskap gerig word en met die media waarmee ons dit oorbring. Aangesien die gesproke taal die belangrikste medium in dié opsig is, sal daar altyd moeite gedoen moet word om verstaanbare Afrikaans te praat. Aangesien terugvoering ook ' $n$ belangrike kommunikasiebeginsel is, sal ons weë moet vind vir effektiewe terugvoering, bv groepsbesprekings, veral met die ouderlinge en diakens wat die "ore" van die gemeente is, en om tydens huisbesoek altyd terugvoeringsgeleenthede te skep.

Predikante moet geleer word om, of minstens daarvan bewus gemaak word dat hulle hul geleerdheid en toerusting prakties gaan maak in hulle bediening.

\section{Ouderlinge}

Die Kerk moet sy ouderlinge weer "mondig" kry. Dit kan veral gedoen word deur ouderlinge beter toe te rus en op te lei vir hulle werk, en dit nie deur net kursusse aan te bied met die oog op groepbesprekings, afbakening van probleemareas en lesings te gee nie (dit is ook absoluut noodsaaklik), maar ook deur praktiese in-diens-opleiding. ' $n$ Paar jaar gelede het daar al by 'n soortgelyke vergadering die gedagte van "voltydse ouderlinge" na vore gekom. Ek is van mening dat daar sterker in dié rigting gedink moet word. 


\section{Diakens}

Diakens moet onthef word van die sloer van "geldversamelaars" te wees, of hierdie las moet dalk net ligter gemaak of minder beklemtoon word. Hulle moet ook eerder opgelei en toegerus word om waarlik die "Rooikruis" van die gemeente te wees deur meer betrokke te raak by lewenskwessies en lewenskrisisse van gemeentelede. (Die opsig het mos te doen met die bevordering van die lewe wat eers werklik sin kon kry deur die versoening in Christus.) Diakens moet veral geleer word hoe om dit te doen wat ons by hulle bevestiging aan hulle opdra: "Daarom is dit goed dat hulle nie net met uiterlike gawes nie, maar ook met gepaste trooswoorde uit die Woord van God aan die armes en ellendiges hulp verleen" (Diensboek, 1978, p 70). Hierop moet ons uitbrei: Nie net aan die armes en die ellendiges nie, maar aan elke gelowige wie se drumpel hy waag om namens die barmhartige Heer van die Kerk te betree.

\section{Vergaderings}

Die Kerk sal die gees, die gesindheid en die werkwyse van sy amptelike vergaderings en hulle kommissies só moet orden dat daar nie regoristies formeel-amptelik opsig gehou word nie, maar dat daar 'n groter betrokkenheid ontstaan by ampsdraers (en hulle gesinne) oor wie die opsig en tug uitgeoefen word. By ampsdraers moet daar ook huisbesoek gedoen word deur die opsighoudende liggame, want myns insiens kan hulle nie opsig hou en nog minder met 'n skoon gewete tug uitoefen as hulle nie eers huisbesoek gedoen het nie.

\section{Bronnelys}

Agenda vir die sesde vergadering van die Algemene Sinode van die Nederduits Gereformeerde Kerk, Oktober 1981.

Calvijn, J. Institutio Christianae Religionis vertaal deur A Sizoo, Meinema, Delft, s j.

Coetzee, JC. Die Kerk se Werk. Kongresreferate van die Werkgemeenskap vir Praktiese Teologie, Pretoria, 1981.

Beukes, JA. Hedendaagse Evangelisasie. (D D (Afd A)) Universiteit van Pretoria, 1983.

Beukes, MJ du P. "Die Kategetiese metode". Referaat vir Predikantevergadering van die Nederduitsch Hervormde Kerk van Afrika, 1982.

De Klerk, WJ. Pastorale Sensitiwiteit. Perskor, Johannesburg, 1974.

De Wet, JI. "Huisbesoek. Hervormde Teologiese Studies, 22 (2 en 3). “Die Opleiding van predikante". Hervormde Teologiese Studies, 30 (3 en 4). 
Dreyer, TFJ. "Die verband tussen prediking/erediens en die lewe van die gemeente". Referaat vir Predikantevergadering van die Nederduitsch Hervormde Kerk van Afrika, 1984.

Fabro, C. God in Exile, vertaal deur A Gibson, Newman Press, New York, 1964.

Häring, B. Evangelization Today, Fides Publishers, Notre Dame, Indiana, 1974.

Heyns, JA. "Sterwende Christendom", 'n Teologie in die greep van die tydsgees. Tafelberg Uitgewers, Kaapstad, 1969.

Kerkwet en Bepalings Nederduitsch Hervormde Kerk van Afrika, 1983.

Bevolkingsensus 1980: Steekproef, Kerkverbandverslag Nr 02-08-02, Staatsdrukker, Pretoria.

Bevolkingsensus 1970: Kerkverbandverslag Nr 02-05-03, Staatsdrukker, Pretoria.

Van Eeden, IJ e a. Kerkspieël. NG Kerkboekhandel, Pretoria, 1982.

Venster op die Kerk. Wetenskaplike bydraes van PU vir CHO, F3:12, 1980.

Venter, HJP. (Die Prediker en die Preekgebeure). Kongresreferaat by die Werkgemeenskap vir Praktiese Teologie, UP, 1984.

Venter, PW. "Sielsorg in die veranderde maatskaplike omstandighede, veral met betrekking tot geïndustrialiseerde gebiede". Heroormde Teologiese Studies, 27 (3 en 4).

Verkuyl, J. Inleiding in die Evangelistiek. Kok, Kampen, 1978.

Walsh, C. Early Christians of the 21st century. Greenwood Press, Westport, 1950. 